\title{
Pengaruh Penambahan Air Perasan Jeruk Nipis (Citrus Aurantifolia) Dalam Air Minum Terhadap Performans Ayam Broiler
}

\section{(The Effect of Added Lime Juice (Citrus Aurantifolia) in Drinking Water on broiler chickens_performance)}

\author{
Setyawan, M.I, Warsono Sarengat, T.A. Sarjana \\ Laboratorium Produksi Ternak Unggas. \\ Fakultas Peternakan dan Pertanian Universitas Diponegoro \\ Jl. Prof. Soedarto, SH Tembalang, Semarang, 1269 Jawa Tengah \\ Email : teysar_adi@undip.ac.id
}

Diterima : 29 Januari 2019

Disetujui : 12 Mei 2019

\begin{abstract}
ABSTRAK
Penelitian ini bertujuan untuk mengetahui pengaruh penambahan air perasan jeruk nipis dalam air minum terhadap performans ayam broiler. Materi yang digunakan yaitu 90 ekor ayam broiler pada umur 1 hari dengan berat badan awal ( $38 \pm 0,1 \mathrm{~g} / \mathrm{ekor}$ ). Perlakuan mulai diterapkan pada umur 21 hari sampai dengan 35 hari. Penelitian ini dilakukan dengan menggunakan rancangan acak lengkap (RAL) dengan 3 perlakuan 6 ulangan. Perlakuan yang diterapkan sebagai berikut: $\mathrm{T}_{0}$ (tanpa perasan jeruk nipis), $\mathrm{T}_{1}(0,5 \%$ perasan jeruk nipis) dan $\mathrm{T}_{2}$ (1\% perasan jeruk nipis). Parameter yang diamati dalam penelitian ini adalah konsumsi pakan, pertambahan bobotbadan, konversi pakan, dan income overfeed cost (IOFC). Hasil penelitian ini menunjukkan bahwa penambahan air perasan jeruk nipis tidak memberikan pengaruh nyata terhadap performans ayam broiler $(P>0,05)$. Dapat disimpulkan bahwa penambahan air perasan jeruk nipis hingga $1 \%$ belum dapat memperbaiki performans ayam broiler.
\end{abstract}

Kata kunci : Ayam broiler, perasan jeruk nipis, performans

\section{ABSTRACT}

This study aims to determine the effect of adding lime juice to the drinking water of broiler chicken for their performance. The material used were 90 broiler chickens at the age of 1 day with initial body weights $(38+0.1 \mathrm{~g} /$ chick). Treatments were applied at the age of 21 days to 35 days. This research conducted using a Completely Randomized Design (CRD) with 3 treatments 6 replications. The treatment was applied as follows : T0 (without lime juice), T1 ( $0.5 \%$ lime juice) and T2 (1\% lime juice). The parameters observed in this study are feed consumption, body weight gain, feed conversion, performance index (IP), and income over feed cost (IOFC). The results of this study indicated that the treatment of lime juice did not show any significant effect on the performance of broiler chickens ( $P>$ 0.05). In conclusion the addition of lime juice up to $1 \%$ has not been able to improve the performance of broilerchickens.

Keywords: Chicken broiler, lime juice, performance 


\section{PENDAHULUAN}

Penambahan asam organik dapat menjaga keseimbangan mikrobia dalam saluran pencernaan dengan cara mempertahankan $\mathrm{pH}$ saluran pencernaan, sehingga penyerapan protein meningkat (Natsir, 2008). Hasil penelitian Rafacz et al, (2005) menyatakan bahwa penambahan asam sitrat sebanyak $2-6 \%$ pada ransum ayam dapat meningkatkan pertambahan bobot badan, efisiensi ransum, atau konversi pakan. Kandungan jeruk nipis menurut hasil penelitian Nour (2010) yaitu mengandung asam sitrat $6,15 \%$, asam malat $0,52 \%$, asam laktat $0,09 \%$, serta sejumlah kecil asam tartarat. Sarijeruk nipis mengandung asam sitrat yang dapat menurunkan $\mathrm{pH}$ saluran pencernaan. Kondisi saluran pencernaan ternak normalnya bersifat netral sehingga saat kondisi asam, tubuh akan membentuk garam empedu dimana fungsi garam empedu yaitu menetralkan saluran pencernaan. Sari jeruk nipis mengandung asam sitrat yang dapat menurunkan $\mathrm{pH}$ saluran pencernaan. Efek acidifier dalam usus halus dapat menekan pertumbuhan bakteri patogen dan meningkatkan pertumbuhan bakteri nonpatogen terutama bakteri asam laktat (BAL) yang mempunyai kontribusi terhadap proses pencernaan. Berkurangnya bakteri patogen dan meningkatnya BAL menyebabkan kecernaan pakan dan penyerapan nutrien dalam usus lebih baik sehingga menghasilkan pertumbuhan lebih baik pula. Hasil penelitian Islam et al. (2008) menunjukan bahwa pemberian asam sitrat $(0,5 \%)$ menunjukkan bahwa hasil berat beratbadan akhiryang terbaik pada ayam broiler. Kopecký et. al. (2012) juga menunjukkan hasil yang sama, bahwa penggunaan asam sitrat memberikan bobot badan akhir yang terbaik pada fase pemeliharaan periode starter 21 hari. Salah satu yang dapat digunakan sebagai acidifier adalah asam sitrat. Salgado dan Tránsito et al., (2011) menyatakan bahwa asam sitrat mampu meningkatkan bobot badan seiring dengan peningkatan level, selain itu juga nyata memperbaiki konversi pakan. Hasil penelitian Aristo et al. (2015) menunjukan bahwa rata-rata konsumsi pakan selama 35 hari pada perlakuan rata-rata 713,81 gram/ekor, pertambahan bobot badan ratarata 194,62 gram/ekor/hari dan konversi pakan rata-rata konversi 3,67 gram.

Tujuan dari penelitian ini adalah untuk mengkaji pengaruh penambahan jeruk nipis terhadap performa ayam broiler. Hipotesis penelitian bahwa penambahan air perasanjeruk nipis sebagai acidifiermampu meningkatkan performans ayam broiler.

\section{MATERI DAN METODE}

Penelitian menggunakan ayam broiler strain Lohman unsex dengan jumlah 90 ekor dan dipelihara mulai umur 1 hari dengan bobot badan $38 \pm 0,1$ g/ekor Perlakuan mulaidi tetapkan pada saat ayam broiler berumur 21 hari dengan bobot badan rata-rata $501,111 \mathrm{~g}(\mathrm{CV}=0,28 \%)$.

Pakan komersial BR-1 dan 201-C diberikan selama masa penelitian. Pakan BR-1 sampai umur 21 hari sedangkan pakan "201"-C sampai umur 35 hari. Kandungan nutrisi ransum dapat dilihat pada Tabel2). Air perasan jeruk nipis ditambah dengan 
$1000 \mathrm{ml}$ air diberikan pada pagi haridan sebagian diberikan pada sore hari. Pakan dan air minum diberikan secara ad libitum. Penelitian disusun menggunakan Rancangan Acak Lengkap yang terdiri dari3 perlakuan dan 6 ulangan tiap unit percobaan terdiri dari 5 ekor ayam. Perlakuan disusun sebagai berikut :
T0: Air minum + tanpa perasanjeruk nipis

$\mathrm{T} 1$ : Air minum $+0,5 \%$ perasan jeruk nipis ( 5 $\mathrm{ml}$ air perasan jeruk nipis $+1000 \mathrm{ml}$ air minum.

T2:Airminum $+1 \%$ perasanjeruknipis $(10$ ml air perasan jeruknipis +1000 mlair minum.

Tabel 1. Konsumsi asam sitrat level pemberian jeruk nipis

\begin{tabular}{cc}
\hline Perlakuan penambahan jeruk nipis (\%) & Konsumsi asam sitrat g/l \\
\hline 0,00 & 0,00 \\
0,50 & 0,08 \\
1,00 & 0,15 \\
\hline
\end{tabular}

Estimasi kalkulasi konsumsi asam sitrat yang terkandung dalam air minum dilakukan berdasar asumsi standart konsumsi air air/ekor/hari dan kandunganasam sitratjeruknipissebesar $5,8 \% / 100 \mathrm{ml}$ (Hasanuddinetal.,2013).

Tabel 2. Kandungan nutrisi BR1-CP5111 dan 201-C²

\begin{tabular}{lcc}
\hline \multicolumn{1}{c}{ Analisa } & BR1- & $201-\mathrm{C}^{2}$ \\
& $\mathrm{CP} 511^{1}$ & \\
\cline { 1 - 2 } Protein (\%) & 23,0 & 20,0 \\
EM & $3.448,0$ & $3.448,0$ \\
\hline Lemak (\%) & 5,0 & 5,0 \\
Serat (\%) & 5,0 & 5,0 \\
Abu (\%) & 7,0 & 8,0 \\
Kalsium (\%) & 0,9 & 0,9 \\
Fosfor (\%) & 0,6 & 0,6 \\
Kadar Air (\%) & 13.0 & 13,0 \\
\hline
\end{tabular}

Keterangan: ${ }^{1}$ : Label kandungan pakan BR1-CP511 PT. Charoen Pokphand dan kandungan pakan 201C PT. Goldcoin Indonesia ${ }^{2}$ : Perhitungan dengan rumus Bolton sebagaimana digunakan dalam Sugiharto et al.(2017).

Paramater dan rumus yang diamati adalah sebagai berikut :

1. Konsumsi Pakan (g/ekor/hari) = pakan yang diberikan $(\mathrm{g})$-sisa $(\mathrm{g})$

2. Pertambahan BobotBadan $(\mathrm{PBB})=$ BB akhir-BB awal

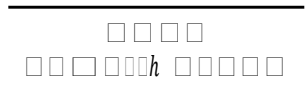

3. Konversi pakan $=\frac{\text { konsumsipakan }(\text { gram })}{\mathrm{BB}}$

4. IOFC $=$ Bobot hidup $(\mathrm{BH}) \times$ harga broiler (Rp)-Konsumsi pakan x Harga Pakan (Rp)

Data yang diperoleh dianalisis dengan menggunakan analisis of varian (ANOVA), dengan uji $F$ untuk mengetahui pengaruh pemberian air perasan jeruk nipis terhadap performans ayam broiler. 


\section{HASIL DAN PEMBAHASAN}

Hasil analisis ragam dari data yang diperoleh pada pengaruh pemberian air perasan jeruk nipis terhadap performans ayam broiler disajikan pada Tabel 3.

Tabel3. Rataan Konsumsi Pakan, Pertambahan Bobot Badan, Konversi pakan dan Income Over Feed Cost

\begin{tabular}{lrrr}
\hline \multirow{2}{*}{\multicolumn{1}{c}{ Parameter }} & \multicolumn{3}{c}{ Perlakuan $^{*}$} \\
\cline { 2 - 4 } & T0 & T1 & T2 \\
\hline Konsumsi Pakan (g) & 2283 & 2431 & 2335 \\
Pbb (g/ekor/hari) & 43.27 & 33.47 & 45.72 \\
Konversi pakan & 2.08 & 2,55 & 2,00 \\
IOFC & 16,309 & 11,041 & 16,895 \\
\hline
\end{tabular}

Keterangan:Perlakuan tidakberbedanyataterhadap parameteryang diamati $(P>0,05)$

\section{Konsumsi Pakan}

Pada penelitian ini hasil konsumsi pakan selama 35 hari adalah2283-2431 g/ekor hasil tersebut lebih kecil dibanding penelitian Kartasudjana dan Suprijatna (2010) yang menyatakan bahwa dalam jangka waktu 5 minggu konsumsi pakan mencapai $2.500 \mathrm{~g}$ dan pencapaian bobot badan $1.500 \mathrm{~g}$. Tingginya nilai akhir konsumsi pakan masih belum meningkatkan bobot badan akhir ayam broiler.

Berdasarkan hasil analisis ragam penambahan perasan jeruk nipis tidak berpengaruh nyata terhadap konsumsi pakan ayam broiler karena kadar asam sitrat taraf $0,08 \%$ dan $0,15 \%$ dalam perasan jeruk nipis yang dikonsumsi masih terlalu kecil $(P>0,05)$. Hal ini sesuai pendapat Atpattu dan Nelligaswatta (2005) menyatakan bahwa penambahan asam sitrat organik sampai level $2 \%$ tidak berpengaruh nyata terhadap konsumsi pakan ayam broiler. Berdasarkan data Tabel 3 , terlalu kecilnya kadar asam sitrat, diduga tidak mempengaruhi laju pakan dan menurunkan konsumsi pakan, sehingga idealnya peningkatan proporsi bahan aktif dalam jeruk nipis berupa asam sitrat dapat meningkatkan konsumsi pakan dengan diikuti peningkatan kecernaan nutrient, sehingga tidak cukup mempengaruhi konsumsi pakan broiler secara signifikan. Hasil penelitian Saputra (2014) menunjukan bahwa penambahan asam sitrat sampai 5 kali lipat dari kami lakukan yaitu sebesar $0,8 \%$ belum mempengaruhi konsumsi ransum.

Pada jumlah konsumsi asam organik berupa asam sitrat yang kecil sebagaimana seharusnya kandungan energi metabolis yang tidak berbeda juga akan berdampak pada jumlah konsumsi pakan yang tidak berbeda nyata. Hal ini sesuai dengan pendapat Aisjah et al., (2007) menyatakan bahwa energi metabolis yang diberikan sama dalam ransum akan menghasilkan konsumsi pakan yang sama, dengan kata lain ransum mengandung protein yang sama sehingga hasil yang diberikan konsumsi protein pun juga sama. 
Pertambahan Bobot Badan dan Konversi Pakan

Pada penelitian ini hasil rata-rata pertambahan bobot badan adalah 33.47$45.72 \mathrm{~g} / \mathrm{ekor} / \mathrm{hari}$ hasil tersebut lebih kecil dibandingkan dengan hasil penelitian Aristo et al., (2015) sebesar 194,63 gram/ekor/hari. Berdasarkan hasil analisis ragam penambahan perasan jeruk nipis tidak berpengaruh nyata terhadap pertambahan bobot badan ayam broiler karenakadar asam sitrat taraf $0,08 \%$ dan $0,15 \%$ dalam perasan jeruk nipis yang dikonsumsi belum meningkatkan pertambahan bobot badan $(P>0,05)$. Pada penelitian Mulyani et.,al (2016) penambahan asam sitrathinggataraf $1,33 \%$ belum berpengaruh nyata terhadap pertambahan bobot badan harian unggas pedaging dan baru mulai berpengaruh pada level 2\% Rafacz et al (2005). Berdasarkan data Tabel 3, kadar asam sitrat yang terlalu kecil, diduga tidak mempengaruhi $\mathrm{pH}$ pada saluran pencernaan dan kecernaan pada protein meningkat sehingga pertambahan bobot badan dan konversi pakan menjadi non signifikan. Hal ini sesuai pendapat Natsir dan Sjofjan (2008) menyatakan bahwa penambahan asam sitrat dan asam laktat dalam ransum tidak memberikan pengaruh karena diduga telah terurai sebelum di usus, sehingga penurunan $\mathrm{pH}$ yang diharapkan untuk menekan perkembangan mikroba patogen belum terjadi secara optimal.

Pada penelitian ini hasil konversi pakan didapat sebesar 2,00-2,55 hasil tersebut rendah. Hasil ini sesuai dengan pendapat Amrullah (2003) dengan rata-rata konversi pakan selama penelitian sebesar
1,87. Berdasarkan hasil analisis ragam penambahan perasan jeruk nipis tidak berpengaruh nyata terhadap konversi pakan ayam broiler karena kadar asam sitrat taraf $0,08 \%$ dan $0,15 \%$ dalam perasan jeruk nipis yang dikonsumsi belum meningkatkan konversi pakan $(P>0,05)$. Menurut pendapat Rafacz et al, (2005) menyatakan bahwa penambahan asam sitrat sebanyak $2-6 \%$ pada ransum ayam dapat meningkatkan pertambahan bobot badan, efisiensi ransum, atau konversi pakan. Berdasarkan data Tabel 3, kadar asam sitrat yang terlalukecil, hal ini diduga tidak mempengaruhi pertumbuhan laju protein yang terus meningkat, infeksi bakteri sehingga mempengaruhi konversi pakan yang buruk. Hal ini sesuai dengan pendapat Soebarinoto (1986) yang menyatakan bahwa infeksi bakteri non patogen dapat menurunkan konsumsi pakan dan mempengaruhi nilai konversi serta efisiensi pakan

\section{Income Feed Over Cost}

Berdasarkan hasil penelitian ini didapatkan rata-rata IOFC yaitu $\mathrm{Rp} 11.041$ 16.895. Hasil tersebut normal dibandingkan penelitian Anggitasari (2016) yang menyatakan bahwa kisaran rata-rata income over feed cost sebesar Rp.9.28410.952. Rendahnya IOFC disebabkan bobot badan akhir yang kecil serta FCR yang tinggi sehingga mengakibatkan biaya pakan yang tinggi. Hal ini sesuai dengan penelitian Rasyaf (2011) menyatakan bahwa semakin tinggi nilai IOFC akan semakin baik pula pemeliharaan yang dilakukan, karena tingginya IOFC berarti penerimaan yang 
didapat dari hasil penjualan ayam juga semakin tinggi.

\section{KESIMPULAN}

Berdasarkan hasil penelitian dapat disimpulkan bahwa penambahan air perasan jeruk nipis hingga $1 \%$ dalam air minum belum mampu memperbaiki performans ayambroiler.

\section{DAFTAR PUSTAKA}

Anggitasari, S., E. Sjofjan, dan I. H. Djunaidi. 2006. Pengaruh Beberapa Jenis Pakan Komersial Terhadap Kinerja Produksi Kuantitatif dan Kualitatif Ayam Pedaging. Buletin Peternakan Vol. 40 (3): 187-196

Amrullah. 2003. Nutrisi Broiler. Lembaga Satu Gunungbudi. Bogor.

Aristo, K. S., R. Oktovianus., T. B. Nahak, A. D. Agustinus. Perbandingan Penggunaan Dua Jenis Ransum Terhadap Pertambahan Bobot Badan Harian (PBBH), Konsumsi Ransum dan Konversi Ransum Ayam Broiler. Journal of Animal Science 1 (1) 1-3

Hasanuddin, S., V.D. Yunianto dan Tristiarti. 2013. Lemak dan Kolesterol Daging Pada Ayam Broiler yang Diberi Pakan Step Down Protein Dengan Penambahan Air Perasan Jeruk Nipis Sebagai Acidifier. Buletin Nutrisi dan Makanan Ternak, Vol 9(1) 2013. ISSN 1411-4577. Fakultas Peternakan dan Pertanian Universitas Diponegoro.
Islam, M.Z. , Z,H. Khandaker, S.D. Chowdhury and K.M.S. Islam. 2008. Effect of citric acid and acetic acid on the performance of broiers. J. Bangladesh Agric. Univ. 6(2):315320

Kartasudjana, R. dan E. Suprijatna. 2006. Manajemen Ternak Unggas. Penebar Swadaya. Jakarta

Kopecky J, Hencar C, Weis J. 2012 Effect of organic acids supplement on performance of broilers chikens. $J$ Anim SciBiotech 45(1): 51-54.

Krismiyanto, L. 2011. Pengaruh sari jeruk nipis ( citrus aurantifolia) terhadap laju digesta dan kecernaan serat kasar pada ayam pelung jantan yang diberi ransum berbasis dedak padi. Fakultas Peternakan UNDIP (Skripsi Sarjana Peternakan UNDIP, Semarang).

Mulyani, T. D. Mahfudz, L. D. danSukamto, B. 2016. Efek penambahan asam sitrat dalam ransum terhadap pertambahan bobot badan dan karkas itik jantan lokal periode grower. J Animal Agriculture 2(4): 11-22

Natsir, M. H. dan O. Sjofjan. 2008. Pengaruh penggunaan kombinasi asam sitrat dan asam laktat cair terenkapsulasi sebagai aditif pakan terhadap penampilan produksi ayam pedaging. Seminar Nasional Teknologi Peternakan dan Veteriner. 636-640.

Nour, V., I. Trandafir, dan M. E. Ionica. 2010. HPLC organic acid analysis in different citrus juices under reversed phase conditions. Notulae 
Botanicae Horti Agrobotanici ClujNapoca Journal. 38: 44-48.

Primandini, Y., L.D. Mahfudz dan B. Sukamto. Interval Waktu Penambahan Ampas Mengkudu (Morinda citrifolia L.) dalam Ransum terhadap Performans Ayam Broiler. J Agripet Vol 12, No. 1, April 2012

Rasyaf, M. 2011. Panduan Beternak Ayam Pedaging. Cetakan ke-4. Penebar Swadaya. Jakarta

Rafacz, K.A., C.M. Parsons and R.A. Jungk. 2005. The Effects of Various Organic Acids on Phytate Phosphorus Utilization in Chicks. Poult. Sci., 84: 1353.

Risnajati, D. 2011. Pengaruh Pengaturan Waktu Pemberian Air Minum yang berbeda Temperatur Terhadap Performan Ayam Petelur Periode Grower.Sains Peternakan Vol.9(2), September 2011: 77-81 ISSN 16938828
Salgado-Tránsito, L., J.C. Del-Río-García, J.L. Arjona-Román, E. Moreno-Martínez, A. Méndez-Albores. 2011. Effect of citric acid supplemented diets on aflatoxin degradation, growth performance and serum parameters in broiler chickens. Arc. Med. Vet. 43: 215-222.

Saputra, W.Y., N. Suthama dan L. D. Mahfudz. 2014. Pemberian Kombinasi Pakan Double Step Down dan Asam Sitrat Sebagai Upaya Peningkatan Efisiensi Usaha Peternakan Broiler. Buletin Nutrisi dan Makanan Ternak. Vol. 10(1), ISSN 1411-4577

Sugiharto, S., T. Yudiarti and I. Isroli. 2017. Effect of Feeding Cassava Puip Fermented with acremonium charticola on growth performance, nutrient Digestibility and meat Quality of Broiler Chicks. Journal of animal Science. South African. Vol $47(2): 130-138$ 